\title{
Recorrido por la jurisprudencia sobre los denominados «Alardes»: una fiesta plagada de conflictos
}

\author{
María Burzaco Samper \\ Profesora de Derecho Administrativo \\ Universidad Pontificia Comillas
}

\begin{abstract}
Resumen: La celebración en diversas localidades vascas de los denominados «Alardes» ha sido fuente de constantes conflictos judiciales desde los años noventa. Sin negar la dimensión sociológica que tales controversias presentan, debe reconocerse que, desde una perspectiva estrictamente jurídica, los procesos judiciales han dado lugar a una jurisprudencia de indudable interés que, por otro lado, ha venido marcada por una evolución significativa en su fundamentación. Este trabajo se ocupa de realizar ese recorrido desde las primeras sentencias, centradas en la vulneración del principio de igualdad, hasta la línea trazada por la STS de 2 de junio de 2003 que, en cuanto consideró el Alarde como manifestación del derecho de reunión, marcó un punto de inflexión en la resolución de estos conflictos recurrentes.
\end{abstract}

Palabras clave: derecho de reunión, espectáculos públicos, principio de igualdad, participación democrática, proceso contencioso-administrativo.

Abstract: The celebration of the so called «Alardes» in diverse Basque localities has been the starting point of constant judicial conflicts since the 90's. Without denying the sociological dimension of such controversies, it must be recognized that, from a strictly legal perspective, the judicial processes have motivated a jurisprudence of doubtless interest that, on the other hand, manifests a significant evolution on its basis. This work covers all this progression from the very first sentences, which somehow put at risk the equality principle, to the new stage marked by the STS of the $2^{\text {nd }}$ of June of 2003 which, as far as it considered the Alarde as a manifestation of the meeting right, marked a point of inflexion in the resolution of these recurrent conflicts.

Key words: meeting right, public spectacles, principle of equality, democratic participation, contentious-administrative process.

Sumario: I. Apuntes Preliminares. - II. Las primeras Sentencias: Alarde y Principio de igualdad. A) Las distintas concepciones sobre el Alarde: Alarde Tradicional frente a Alarde Igualitario; B) La posición de las Corporaciones Locales en la celebración de los Alardes: variaciones y estrategias; C) Mención específica a ciertas cuestiones procesales. III. El Alarde como ejercicio del Derecho de reunión. A) Los hechos que dieron lugar a un nuevo recurso contencioso-administrativo; B) Naturaleza del Alarde; C) Sobre el objeto del proceso; D) La postura discrepante del Tribunal Supremo; 1. Alarde y Derecho de reunión; 2. En cuanto a la 
actuación policial; E) Síntesis de la doctrina del Tribunal Constitucional sobre el Derecho de reunión; F) Nuestra crítica a la STS de 2 de junio de 2003. - IV. La respuesta judicial al último conflicto: Sentencia del tribunal Superior de Justicia del País Vasco de 21 de junio de 2005. A) Objeto del proceso; B) Legitimación activa y art. 122.1 LJCA; C) Los argumentos de la Asociación recurrente y la respuesta judicial a éstos. V. Consideraciones Finales.

\section{Apuntes preliminares}

Los conflictos suscitados en torno al «Alarde tradicional» (en adelante, AT) y al «Alarde igualitario» (en adelante, AI) se han convertido en una cuestión de puntual aparición en la agenda judicial desde los años noventa.

Independientemente del alcance que desde los medios informativos se ha dado a las controversias y disputas entre los grupos implicados, lo cierto es que en el plano jurídico han originado un buen número de resoluciones judiciales en las que se evidencia que estamos ante un problema jurídicamente complejo que entremezcla extremos de muy diversa índole. Por otro lado, la propia actitud que, tras las primeras Sentencias, adoptaron tanto las instituciones públicas - Corporaciones municipales de las localidades vascas de Hondarribia e Irún-, como los promotores de los distintos Alardes ha coadyuvado a alterar el signo de tales conflictos dando pie a una jurisprudencia de indudable interés.

Con carácter previo debe explicarse que el Alarde constituye una manifestación popular de tipo festivo que posee, además, una nota de conmemoración de ciertos acontecimientos históricos ${ }^{1}$ en el que residen aspectos de distinto carácter: festivos, cívicos, sociales y religiosos. Esta circunstancia ha planteado, paralelamente, una dificultad de primer orden en cuanto a la naturaleza del propio acto y el régimen jurídico al que está sometido. Un extremo de consecuencias relevantes en lo atinente no sólo a la normativa aplicable, sino también a los aspectos y cauces procesales a través de los que los referidos conflictos debían canalizarse.

De todo ello es buena prueba el análisis de la ya prolija jurisprudencia en torno a esta figura, cuestión que centra este estudio.

\footnotetext{
${ }^{1}$ Las disputas se han producido en dos localidades vascas, Hondarribia e Irún, en las que se conmemoran sendos hechos de armas. Concretamente en la primera de ellas, los acaecidos el 7 de septiembre de 1638 para el levantamiento del sitio a que les sometieron las tropas francesas. Por su parte, en Irún, se rememora la batalla de Peña de Aldabe, ganada por las milicias forales en 1552.
} 


\section{Las primeras Sentencias: Alarde y Principio de igualdad}

\section{A) Las distintas Concepciones sobre el Alarde: Alarde Tradicional frente a Alarde Igualitario}

Los conflictos sobre los Alardes tienen su origen en el distinto entendimiento que los ha inspirado: los promotores del AT esgrimen un supuesto purismo que se materializaría en la escenificación fiel de los hechos históricos conmemorados y que explicaría una neta distinción en el protagonismo asignado a hombres y mujeres, generalmente con la postergación de éstas a un papel secundario. Por el contrario, el llamado AI posee un carácter reivindicativo por el que se propugna la participación indistinta de hombres y mujeres en cualesquiera de los roles que tienen entrada en el Alarde.

Partiendo de esta diversidad de concepciones, los primeros procesos judiciales tuvieron su origen en resoluciones municipales denegatorias de peticiones de participación en régimen de igualdad en los Alardes correspondientes. Ha de tenerse en cuenta que en aquel momento los respectivos Ayuntamientos eran los organizadores de tales eventos que, además, contaban con Ordenanzas que vinculaban a sus órganos (más específicamente al Alcalde) a la Junta del Alarde y lo regulaban en diversos aspectos. Planteados los pertinentes recursos contencioso-administrativos contra las denegaciones de participación igualitaria, las sentencias que los resolvieron entendieron que la actuación municipal incurría en vulneración del principio de igualdad constitucionalmente reconocido (art. $14 \mathrm{CE}$ ), con base en los siguientes fundamentos:

Es un hecho irrefutable que el grado de participación de hombres y mujeres en los actos de los Alardes no es en modo alguno equiparable. Sin embargo, esta circunstancia por sí sola no contraviene el principio de igualdad. Dilucidar esta cuestión nuclear pasaba por perfilar la naturaleza del Alarde y los derechos o intereses que afectaban a los interesados. Los partidarios del AT defendían que esta celebración consiste en una mera reproducción y puesta en escena de los correspondientes acontecimientos que se conmemoran, de suerte que el distinto papel desempeñado por hombres y mujeres no es sino el reflejo fiel del suceso histórico.

Este argumento se rechaza con base tanto en argumentos históricos ${ }^{2}$ como en la propia dicción literal del término rememorar que, conforme

\footnotetext{
${ }^{2}$ En relación con el Alarde de San Marcial de Irún, la STSJPV de 17 de enero de 1998 en sus FJ $6 .^{\circ}$ y $7 .^{\circ}$ hace un extenso análisis de los hechos históricos que aquél conmemora y que fueron objeto de una también amplia prueba pericial, concluyendo que el Alarde posee «caracteres rememorativos seguramente ciertos», aunque presenta igualmente «una significación social, festiva y participativa insoslayable». STSJPV (Sala de lo Contencioso-Administrativo; Sección 1.a) núm. 16/1998, de 17 de enero de 1998; recurso núm. 774/1997. Referencia El Derecho Editores (en adelante, EDE) 1998/24109.
} 
determina la STS de 19 de septiembre de $2002^{3}$, «alude al simple recuerdo de un hecho pasado, cualquiera que sea la manera elegida para su evocación» y que, en suma, «puede efectuarse mediante una escenificación o también a través de actuaciones de naturaleza diferente, como puede ser una celebración festiva en la que intervengan los actuales miembros del pueblo o la colectividad a que se refiere el hecho histórico» (FJ 4. ${ }^{\circ}, a$ y $b$ ).

Esta misma sentencia resalta que "podría resultar comprensible una exclusión femenina, si el único propósito es ofrecer en la actualidad una imagen plástica del suceso histórico que reproduzca con total exactitud cuál fue su realidad material». «Sin embargo, en las celebraciones festivas de carácter popular, cuando son organizadas en el marco de actividades de una Administración Pública y con sujeción a la regulación reglamentaria que por ella haya sido establecida, la exclusión femenina resulta injustificada, pues equivaldría a admitir que en razón del sexo se pueden establecer diferentes grados de participación ciudadana en esa clase de acontecimientos. El riguroso canon de legitimidad que ha de ser aplicado a las diferenciaciones por razón de sexo, aplicado al presente caso, significa que la exclusión de mujeres en el Alarde de San Marcial, para ser considerada justificada, exigiría inexcusablemente que el Alarde (...) fuera sólo una representación histórica, y que estuviera acreditado que la costumbre de su celebración reflejó en todo momento el inequívoco propósito popular de escenificar con absoluta fidelidad el acontecimiento que se quiere recordar» (FJ $4^{\circ}, c, d$ y $\left.e\right]$

A estos argumentos cabe añadir el contenido en el FJ 5..$^{\circ}$ de la STS de 13 de septiembre de $2002^{4}$ donde, de manera contundente, se afirma:

«...corresponde a dicha Administración, como Poder Público, promover las condiciones que hagan real la igualdad, remover los obstáculos que la impidan o dificulten, y facilitar la participación de todos los ciudadanos en la vida política, económica, cultural y social, a tenor de los arts. 1.1 y 9.2 de la Constitución, de modo que, sea cual sea la naturaleza del evento, ostenta éste, sin duda, una dimensión popular que se desarrolla en el municipio, sin que las instituciones públicas de éste puedan inhibirse como si de algo absolutamente ajeno se tratara o como si de desarrollara poco menos que en la estratosfera, lo que bien puede quedar reforzado cuando derechos fundamentales y principios o valores superiores andan en juego (...)».

\footnotetext{
${ }^{3}$ STS (Sala 3. ${ }^{\text {a }}$; Sección 7. ${ }^{\text {a) }}$, de 19 de septiembre de 2002; recurso núm. 2241/1998. EDE $2002 / 39444$.

${ }^{4}$ STS (Sala 3. a.; Sección 7. ${ }^{\text {a) }}$ ) de 13 de septiembre de 2002; recurso núm. 2239/1998. EDE 2002/35060.
} 
B) La posición de las Corporaciones Locales en la celebración de los Alardes: variaciones y estrategias

Hemos indicado con anterioridad que las controversias se suscitaron inicialmente en momentos en los que las Corporaciones municipales tenían una posición activa en la celebración de los correspondientes Alardes desde un doble plano: por una parte, como organizadores de los actos festivos que, en mayor o menor proporción, eran también sufragados con fondos públicos; $y$, por otro lado, mediante el ejercicio de su potestad reglamentaria dictando, a través de Ordenanzas, normas reguladoras de diversos aspectos concernientes al propio Alarde.

En ese sentido, hubo algunos intentos de desmarcar las controversias de la actuación municipal que, sistemáticamente, fracasaron en la instancia judicial. Especialmente significativo es el caso resuelto por STSPV de 17 de enero de 1998, en el que la Alcaldía de Irún alega la inadmisibilidad del recurso aduciendo que el Ayuntamiento se ciñó a comunicar un acto de la Junta del Alarde, argumento que mereció la siguiente respuesta:

«(...) el Alcalde de Irún preside la Junta del Alarde, mas con carácter fundamental es el órgano unipersonal que preside, dirige el gobierno y la administración municipal y representa a la Corporación Local que ordena el Alarde por medio del ejercicio de competencias normativas y de ejecución amplísimas —artículo 21.1 Ley de Bases de Régimen Local 7/1985, de 2 de abril—. Desde ambas perspectivas las atribuciones que le adornan resultan de la máxima relevancia a la hora de posibilitar la intervención de personas o grupos en el acto público conmemorativo de que se trata y de sintetizar la posición del poder público local al respecto, y ante la solicitud de las administradas podía haber adoptado distintas opciones, ninguna de las cuales tachables de incompetencia o abuso de sus facultades, capacidades y atribuciones. Podrá decirse acaso que, por su sola autoridad no estaba facultada la Alcaldía para derogar preceptos de una Ordenanza hipotéticamente opuestos a la pretensión, ni para interpretar y aplicar sin preceptivas consultas la misma de manera satisfactoria para el ejercicio del derecho. Pero ese mismo fenómeno se concita con carácter muy frecuente respecto de la actividad normal de ejecución y aplicación de las disposiciones de carácter reglamentario por parte de cuantos órganos de la Administración están llamados a hacerlo, y no por ello se puede desconocer la afección de sus resoluciones denegatorias a los mencionados derechos fundamentales.

De otra parte, el esquema de organización competencial de la Administración local lleva a que órganos inferiores o distintos al Pleno o al Alcalde sólo pongan fin con sus actos a la vía administrativa cuando actúan por delegación o lo establezca una disposición legal, —artículo 52 Ley de Bases de Régimen Local de 2 de abril de 1985-, y no consta así que la Junta del Alarde cuente con atribuciones activas o directamente ejecutivas ni que pueda poner fin a la vía administrativa (por más que se le atribuya una facultad de revisión o examen de decisiones y de solventar 
dudas que lo es, por hipótesis respecto de la interpretación y aplicación que hacen otros órganos), mientras que materias con un sentido análogo, como la formación de nuevas compañías, quedan a la aprobación del Ayuntamiento, que resuelve "a la vista del informe que al respecto emita la Junta Municipal del Alarde» - artículo 15-. De ahí deducimos que ningún otro órgano municipal distinto de la Alcaldía o del Pleno podría haber sido estrictamente competente para dictar un pronunciamiento último sobre la cuestión sometida a debate, y no es preciso extenderse demasiado sobre la amplitud competencial de los Alcaldes, tanto por enunciación expresa como por la cláusula de cierre del artículo 21.m LBRL, STS de 10 de noviembre de 1992 o de 27 de febrero de 1997.

Lo que singulariza entonces la afección del ejercicio del derecho fundamental invocado por parte de la Resolución o acto recurrido en este proceso, que requiere el citado artículo $6 \mathrm{LPJDF}$, es que «a limine» y sin siquiera otros trámites, iniciativas, razonamientos o exposición de obstáculos procedimentales que pudieran embargar su actuación, la Alcaldía, tomando y asumiendo implícitamente el contenido de una previa interpretación de la Ordenanza respecto de la exclusiva participación de los varones, responde de manera tal que el ejercicio del derecho fundamental queda frustrado o rechazado, en lo que es un acto de aplicación implícita pero concluyente y eficaz del criterio, normativo o interpretativo, contrario a la participación de las mujeres en dicha manifestación popular. Y esa resulta ser la voluntad de la Administración demandada, manifestada a través de quien la dirige y ejerce representación de la misma, que se combate en el presente recurso» $\left(\mathrm{FJ} 3 .^{\circ}\right)$.

Las resoluciones judiciales a las que hemos hecho referencia, determinaron un «cambio de estrategia» a partir del cual las Corporaciones municipales pasaron a ocupar un segundo plano en la celebración de los Alardes, limitándose al ejercicio de la potestad autorizatoria contemplada en la normativa sectorial sobre espectáculos públicos. Así las cosas, y no siendo ya el Ayuntamiento correspondiente el dinamizador de los mismos sino fundaciones y asociaciones de naturaleza estrictamente privada, las eventuales solicitudes de participación igualitaria perdieron su original sentido.

Los conflictos continuaron con puntual periodicidad, pero su construcción jurídica difería necesariamente de la mantenida en los primeros tiempos, variando asimismo el objeto de los procesos judiciales. Este hecho queda subrayado en la STSJPV de 7 de octubre de $1999^{5}$ en la que, ante la alegación de inadmisibilidad por litispendencia ${ }^{6}$, el órgano jurisdiccional recuerda que en el caso aludido, la pretensión se centraba en «el reconoci-

${ }^{5}$ STSJPV (Sala de lo Contencioso-Administrativo; Sección 1. a) núm. 739/1999, de 7 de octubre de 1999; recurso núm. 4434/1998. EDE 1999/33704.

${ }^{6}$ Ésta se producía en relación con el recurso de casación contra STSJPV de 16 de enero de 1998, finalmente resuelto por la STS de 13 de septiembre de 2002, ambas comentadas en el epígrafe anterior. 
miento de la una situación jurídica relativa a la participación igualitaria de varones y mujeres en el Alarde», mientras que en el supuesto al que se enfrentan «la razón petitoria del recurso se refiere a obligaciones de las Entidades Locales respecto de la organización de tal acontecimiento (...), y subsidiariamente, a la autorización de su celebración con arreglo a las previsiones de la Ley vasca reguladora de los espectáculos públicos, y puede afirmarse que ni desde el primero de los prismas existe una coincidencia de objetos entre ambos procesos ni la causa de pedir es la misma»(FJ 2. ${ }^{\circ}{ }^{7}$. Como puede advertirse, estamos ante un tipo de pretensión muy distinta a la de los primeros recursos: aquí, las recurrentes elevan una petición al Ayuntamiento (concretamente al de Hondarribia) para que éste organizara el Alarde o, subsidiariamente, autorizase su organización a la Asociación actora. Denegada la solicitud, se formula recurso ante la Sala que realiza una interesante precisión señalando que cabe hablar de «organización» de los Alardes en un doble sentido (FJ 3. ${ }^{\circ}$ ):

a) Como «entramado de festividades patronales (...) que, con muy alta probabilidad, son aprobadas, programadas y, total o parcialmente, financiadas desde el ámbito municipal». Desde esta perspectiva, el Alarde es público y por tanto, las actividades desarrolladas en torno a él, no quedan sometidas a previa intervención administrativa autorizatoria. «Ahora bien, el carácter implícito de esa autorización no podrá excluir, sino que presupondrá en todo caso, el sometimiento del acto a los estándares de seguridad y «minimun» ético-jurídico que se especifican en el artículo 18 de dicho texto legal [refiriéndose a la legislación autonómica sectorial de espectáculos públicos], y que comprenden la exclusión de toda conculcación de los derechos fundamentales de las personas». Dicho carácter público impregna todo lo que tenga que ver con el Alarde que, por lo demás, y con base en determinadas Ordenanzas, se vincula a la Administración municipal tanto en el pla-

${ }^{7}$ Este mismo FJ 2. ${ }^{\circ}$ prosigue diciendo: «Presupuesto que lo que delimita objetivamente la pretensión ejercitada no son los motivos impugnatorios o alegatorios empleados por la parte, sino el fundamento de lo que se pide, que se identifica, al menos en una pretensión de reconocimiento de situación jurídica individualizada, con la razón jurídica especifica en que se funda y que se sintetiza en la cuestión suscitada por el recurso, en uno y otro proceso es diverso no sólo el pedimento y objeto procesal de que se reconozca una situación jurídica individualizada en un caso y se asuma una obligación legal en otro por vía de petición, o se autorice el ejercicio de un derecho, sino también (...), el fundamento de significación jurídica de que la pretensión recibe su causa y del que deriva el postulado de congruencia de que el órgano jurisdiccional haya de pronunciarse, "sobre la misma causa que se alegó para deducir las pretensiones". - SSTS de 5 de octubre de 1995, o 26 de julio de 1996-. Así, la causa de pedir, que es un elemento de la pretensión, es ahora y entonces diferente, puesto que la razón objetiva de pretender es, o bien el derecho a al igualdad, o bien, la posición de la Entidad Local en el entramado legal acerca de los bienes culturales o, en origen, el derecho de la parte actora a ser autorizada para la celebración de un espectáculo público». 
no funcional (mediante el otorgamiento de facultades decisorias al Ayuntamiento que se erige así en fiscalizador de las actividades organizativas), como en el orgánico (incorporando la Alcaldía a la Junta del Alarde). Es precisamente «esa vinculación especial con un Poder público democrático y sometido a la Constitución y las leyes, lo que determina el contenido de esa fiscalización y su orientación hacia la aplicación del postulado fundamental que obliga a aquel a promover condiciones de igualdad y, "a facilitar la participación de todos los ciudadanos en la vida política, económica, cultural y social" —artículo 9.2 CE-, como vinculación decisivamente más fuerte que aquella otra que la Administración demandada esgrime acerca de la salvaguarda de sus formas y signos tradicionales, por importantes que éstos resulten».

b) La organización puede entenderse también como asunción de todas las tareas de ejecución que el Alarde comporte (diseño de las compañías, selección de participantes, puesta en escena, regulación de indumentarias, actuaciones, etc.), lo cual, sin duda, no constituye una obligación municipal «ex lege». La Sala recuerda que el art. 25 LBRL describe ámbitos competenciales locales, siendo el art. 26 del mismo cuerpo legal el que contiene el listado de servicios de prestación obligatoria por parte de los Municipios (lo que implica, correlativamente, el derecho de los vecinos a exigir dicha prestación). De cualquier modo, ni de esta normativa general, ni de la sectorial en su caso aplicable $^{8}$, se colige la existencia de una obligación exigible al Municipio en cuanto a la organización directa del Alarde.

\section{C) Mención específica a ciertas cuestiones procesales}

Algunos de los recursos interpuestos evidenciaron las implicaciones procesales derivadas de la dificultad de perfilar la naturaleza jurídica de los Alardes.

La mayoría de los procesos mencionados se sustanciaron conforme a la antigua Ley 62/ 1978, de 26 de diciembre de Protección Jurisdiccional de los Derechos Fundamentales de la Persona ${ }^{9}$. Sin embargo, la desvinculación de las Corporaciones públicas respecto a estos eventos y el hecho de que, a la vista de los altercados de orden público producidos en varias convocatorias, los distintos promotores de éstos procedieran a comunicarlos a la autoridad

${ }^{8}$ Se alude específicamente a la Ley de Patrimonio Cultural Vasco (Ley 7/1990, de 3 de julio) que atribuye a los entes locales la «misión de realzar y dar a conocer el valor cultural de los bienes integrantes del patrimonio histórico del pueblo vasco que radiquen en su término municipal».

${ }^{9}$ Derogada parcialmente por la Disposición derogatoria 2. ${ }^{a}$ LJCA, norma que actualmente regula este procedimiento como uno de los especiales en el Capítulo Primero, del Título V. 
autonómica competente, dio lugar a variaciones importantes en los procesos judiciales. Es elocuente, a estos efectos, la STSJPV de 7 de septiembre de $2000^{10}$ en la que, resolviendo el recurso contencioso interpuesto por los partidarios del AT contra una Resolución del Director de Seguridad Ciudadana del Departamento de Interior del Gobierno Vasco ${ }^{11}$, la Sala declara la inadmisibilidad del recurso por la inadecuación del procedimiento (arts. 88.1.b) y 68.1.a) LJCA), en cuanto entiende que el Alarde no implica ejercicio de derecho fundamental alguno (cuestión que abordaremos más detalladamente en el epígrafe III), y por tanto, el cauce procesal empleado resultaba de todo punto improcedente ${ }^{12}$.

Por otro lado, la confusión entre «compañías» de desfile, asociaciones y/o fundaciones promotoras del Alarde, y por qué no decirlo, el empleo de tendenciosos subterfugios por parte de los grupos implicados, se ha vuelto en contra de los propios recurrentes en ciertas ocasiones. Así ocurrió en el caso resuelto por STSJPV de 14 de diciembre de $2001^{13}$ que apreció la inadmisibilidad del recurso por falta de legitimación activa de la recurrente. En este caso, una de las Asociaciones defensoras del AI (parte en buen número de los procesos a los que estamos aludiendo), formuló recurso contencioso sin que quedara constancia en autos de la relación existente entre ella y la Compañía bajo cuyo nombre desfilaba el AI, y sin que hubiera referencia alguna en el expediente administrativo a su presencia como parte interesada. Este hecho llevó indefectiblemente a que el Tribunal apreciara la falta de legitimación activa al no manifestarse en el recurso que se hubiera violado derecho fundamental ni interés legítimo alguno - propio o de sus asociados-, ni acreditarse, en este último caso, la habilitación para defender derechos o intereses legítimos colectivos (art. 19.1 $a$ y $b$ LJ).

\section{El Alarde como ejercicio del derecho de reunión}

\section{A) Los hechos que dieron lugar a un nuevo recurso contencioso-adminis- trativo}

Los sucesos acontecidos el 8 septiembre 1998 en Hondarribia dieron pie a un nuevo procedimiento jurisdiccional que, finalmente, supuso un giro

\footnotetext{
${ }^{10}$ STSJPV (Sala de lo Contencioso-Administrativo; Sección 1. a) núm. 458/2000; recurso núm. 1622/00.

${ }^{11}$ Dicha Resolución establecía la posición de las compañías en el desfile del Alarde «sin solución de continuidad», acordando que los defensores del AT lo hicieran inmediatamente después que los del AI.

${ }^{12}$ Se alude al procedimiento especial para la protección de los derechos fundamentales de la persona, y en concreto el establecido en el art. 122 LJCA, relativo al derecho de reunión.

${ }^{13}$ STSJPV (Sala de lo Contencioso-Administrativo; Sección 3. a), núm. 1209/2001, de 14 de diciembre de 2001; recurso núm. 2115/99. EDE 2001/76063.
} 
relevante en la doctrina jurisprudencial sobre los Alardes. Los incidentes se produjeron cuando la Compañía defensora del AI trató de incorporarse al AT provocándose a partir de aquel momento forcejeos, insultos y, a la postre, la intervención de la policía autonómica vasca que, formando un cordón, imposibilitó la participación de la primera en los actos. Estos hechos llevaron a la interposición ante el TSJPV de un recurso contencioso-administrativo que fue resuelto por sentencia de 11 de febrero de $2000^{14}$. Resolución judicial que, al margen de su posterior anulación por STS de 2 de junio de 2003, presenta argumentos jurídicos notablemente trabados dando solución a cuestiones jurídicas de considerable complejidad. De ello nos ocuparemos a continuación.

\section{B) Naturaleza del Alarde}

Planteada esta cuestión de un modo indirecto, la Sala niega de manera tajante que estemos ante el ejercicio de derechos fundamentales, remitiéndose a los fundamentos jurídicos de la STJPV de 7 de octubre de 1999 que, en lo referido a la cuestión sustantiva, había realizado dos precisiones de importancia:

a) De un lado, el Alarde no tiene ligazón posible con el derecho a la libertad religiosa consagrado en el art. $16 \mathrm{CE}$ y regulado por LO 7/1980, de 5 de julio: siendo «rasgo general de impregnación religiosa de origen de un sinfín de celebraciones y festividades locales de nuestra geografía, ninguno ofrece tal acontecimiento de entre los caracteres de un acto de manifestación o adoración religiosa, sino que antes bien, tanto por su fisonomía externa — desfile de numerosos vecinos con indumentarias, armas y demás parafernalias militares de época-, como por la completa ausencia de toda simbología o iconografía religiosa explícita y visible, sus ministros de culto, ceremonias y ritos, constituye exaltación netamente cívica y participativa, de valores identitarios, hechos históricos de armas, tradiciones, culturas o modos de ser colectivos» (FJ 4. ${ }^{\circ}$ ).

b) Asimismo, «menos aún puede aceptarse si cabe que esa representación o puesta en escena de la marcha de un antiguo ejercito se inscriba en el ejercicio del derecho político de reunión y manifestación de la Ley Orgánica 9/1.983, de 15 de julio, que (...) nunca podrá esgrimirse desde la perspectiva en que se hace, como si su entrada en escena dependiese del mayor o menor grado de alteración del orden público y de eventual intervención de la fuerza pública que se presu-

${ }^{14}$ STSJPV (Sala de lo Contencioso-Administrativo; Sección 1. a) núm. 94/2000, de 11 de febrero de 2000; recurso núm. 4359/1998. EDE 2000/5030. 
miese como derivación de un acto, y no en cambio del contenido de éste. La jurisprudencia del Tribunal Constitucional ha puesto de relieve que la finalidad de ese derecho fundamental de reunión pacífica y sin armas es la exposición de ideas - de ahí su enlace con la libertad de expresión-, y la defensa de intereses o la publicidad de problemas y reivindicaciones, a través de una agrupación o asociación transitoria de personas, y nada de esto se compadece mínimamente con la invocación de tal Derecho de Reunión para todo otro fin legitimo - cultural, religioso, festivo, etc.—, que suponga la medial concurrencia concertada de un numeroso grupo de personas en lugares de tránsito público (...). Específicamente la STC 85/1988, 28 abril (...) diferencia entre el requisito de finalidad lícita y la concreta finalidad de la reunión - elemento externo al puro contenido del Derecho de Reunión-, que funciona como condición legitimadora, "pero no como contenido del mismo en el sentido de que cualquier actividad lícita pueda ser realizada por el cauce del derecho de reunión al margen del régimen legal y reglamentario al cual esté sometida, pues ello entraña una inaceptable desnaturalización del derecho en la que se invierten los términos que lo relacionan con su finalidad», y aclara que, «con independencia del derecho a reunirse que tengan las personas que pretenden alcanzar una finalidad lícita determinada, la actividad a realizar para satisfacerla no queda, por ello, exenta de cumplir las condiciones de legalidad que les imponga el ordenamiento jurídico, y no entenderlo así conduciría a la conclusión absurda de que el Derecho de Reunión suprime las potestades administrativas de intervención en las actividades privadas con sólo que un número suficiente de personas decidan realizarlas»-F.J. 3-. Podrá objetar válidamente la Administración demandada que tal iniciativa no le es propia sino de una entidad privada defensora del «Alarde tradicional» integrada por los mandos de éste, pero tal circunstancia nunca le exonerará del cumplimiento de sus propios deberes constitucionales y legales como Administración local».

\section{C) Sobre el objeto del proceso}

Otra de las dificultades que se planteó en el presente caso fue el sometimiento a revisión jurisdiccional de una actuación policial verificada «de facto», esto es, sin procedimentalización y elemento formal previo. Tras citar la doctrina sentada en STC 160/1991, 18 julio $^{15}$, la Sala distingue dos supuestos:

${ }^{15}$ STC (Sala 2. ${ }^{\text {a }}$ ) 160/1991, de 18 de julio; recurso núm. 831/1988. BOE 190/1991, de 9 de agosto. 
«la del acto "de urgencia” manifestado por la fuerza, en que decisión y ejecución se confunden. Y la del acto administrativo con decisión previa y separada, producida mediante forma no escrita adecuada al normal ejercicio jerárquico de la competencia —orden verbal interna (...) — pero de carácter implícito y sólo manifiesto a través de actos de los Agentes de la Administración».

Pues bien, a efectos del enjuiciamiento de la legalidad de la actuación impugnada, el Tribunal entiende que, si bien y tal y como se ha constatado con anterioridad, no estamos ante el ejercicio del derecho de reunión, sin embargo, se da la «necesaria traslación a este supuesto de las doctrinas que han tomado cuerpo en torno al art. 21 CE». Así las cosas, «el límite al ejercicio del derecho de reunión (...) se materializa en que la autoridad policial pueda adoptar, no sólo las medidas pertinentes para posibilitar el ejercicio en libertad del derecho de los manifestantes, o la protección de derechos y bienes de titularidad de terceros, sino que queda legitimada, "en orden a alcanzar tales objetivos, a modificar las condiciones del ejercicio del derecho de reunión e incluso prohibirlo, siempre que concurran los motivos que la CE exige, y previa la realización del oportuno juicio de proporcionalidad" (FJ 2. ${ }^{\circ}$, STC 66/1995, 8 mayo)». Aplicando estas ideas al supuesto enjuiciado, la Sala declara:

El Alarde se configura como «ejercicio de una facultad de participación cívica en la que está comprometida, por lo menos en su aspecto reaccional frente a las actitudes y comportamientos lesivos, el principio de igualdad y el derecho a no sufrir discriminaciones especificas del artículo 14 CE, en relación con el artículo 9.3, ya sea por razón de sexo, o ya se considere trasmutado por derivación este concepto en una discriminación por la mera condición social minoritaria de los partidarios activos de la participación femenina en los Alardes, con pleno respaldo jurisdiccional». Por otro lado, y considerando que «la ponderación de intereses a la que se ve obligada la fuerza policial es análoga a la que ante el Derecho de Reunión se le plantearía, debiendo arbitrar proporcionalmente entre participación igualitaria y seguridad de personas y bienes»; teniendo en cuenta asimismo que la Asociación recurrente había comunicado con la suficiente antelación a la policía autonómica su intención de celebrar el acto conmemorativo, solicitando además la adopción de las medidas de seguridad necesarias para los participantes, «se pone de manifiesto que las medidas finalmente adoptadas sobre el terreno, (...) sólo condujeron tendencial y objetivamente a excluir la participación de uno de los grupos, sobre la base exclusiva de consideraciones técnicas, puntuales e inmediatas de seguridad pública y del más pronto restablecimiento del orden externo en riesgo de alteración», con «completo desentendimiento hacia las demandas anticipadas de seguridad y protección que dicho colectivo social dirigía fundadamente y cuya implementación posibilitaba, al menos, el diseño de medidas y dispositivos restrictivos preestablecidos que armonizasen hasta donde fuese posible todas las facultades legitimas en presencia» (FJ 5. $)$. 
Desde todas estas consideraciones, la Sala entiende que la actuación policial incurrió en «una constitucionalmente ilegítima incidencia sobre el principio de no discriminación», procediendo así a la estimación del recurso.

\section{D) La postura discrepante del TS}

La sentencia que acabamos de exponer fue objeto de recurso de casación interpuesto por el Gobierno Vasco; casación que fue estimada por la citada STS de 2 de junio de 2003 al discrepar en los dos aspectos fundamentales del contenido de aquélla:

\section{AlaRde y DeRECHO DE REUNIÓN}

En lo concerniente a la naturaleza del Alarde, la resolución judicial da un giro decisivo en cuanto reconduce aquél al ejercicio del derecho fundamental de reunión en los siguientes términos:

«Por lo que se refiere al título jurídico en virtud del cual se celebró el Alarde de 1998, es nuestro parecer que se trata del derecho de reunión y manifestación reconocido por el artículo 21 de la Constitución. Derecho que asistía tanto a quienes promovieron su ejercicio desde la "A. F. H" [AT] como a quienes lo hicieron desde la "C. J." [AI]. A esa conclusión llegamos, no sólo porque unos y otros se acogieron a las normas que lo regulan y porque la demanda de la Asociación "J.M." se construye sobre él, sino porque la realidad de los hechos así lo pone de manifiesto. Grupos distintos de personas se reunieron pacíficamente y sin armas, pues las que portaban únicamente tenían el sentido de completar el atuendo y de servir para salvas, con el propósito de manifestar públicamente las ideas que les animan entre las que se incluyen, junto a la conmemoración de un acontecimiento histórico y la renovación del voto a la Virgen de Guadalupe, las que se refieren al acto mismo del Alarde, pues sobre esa celebración de carácter cívico y religioso se mantienen dos concepciones diferentes en torno a la participación de la mujer. (...)

Se dan, pues, los elementos que según la jurisprudencia constitucional identifican el derecho de reunión. Así, dice la Sentencia del Tribunal Constitucional 42/2000: "Cuando se ejercita en lugares de tránsito público es una manifestación colectiva de la libertad de expresión ejercitada a través de una asociación transitoria de personas que opera a modo de técnica instrumental puesta al servicio del intercambio o exposición de ideas, de la defensa de intereses o de la publicidad de problemas o reivindicaciones, constituyendo, por tanto, un cauce relevante del principio democrático participativo, cuyos elementos configuradores son el subjetivo -agrupación de personas-, el temporal -duración transitoria-, el finalista -licitud de la finalidad - y el real u objetivo -lugar de celebración-(SSTC 55/1988, 28 abril, FJ 2. ${ }^{\circ}$-Ref. EDE 1988/371-y 66/1995, 8 mayo, FJ 3. ${ }^{\circ}$-Ref. EDE 1995/2054-)". 
Desde luego, en los actos de Hondarribia se aprecia un claro propósito participativo pero eso (...) es algo que caracteriza el ejercicio típico del derecho de reunión y manifestación y no lo transforma en la innominada facultad de participación cívica que aprecia la sentencia de instancia (...). Así, pues, estamos ante el ejercicio de este derecho fundamental y el mismo asiste tanto a quienes pretenden ejercerlo para celebrar el Alarde de un modo como a los que creen que debe realizarse de otro distinto. También cabe decir que, existiendo distintas concepciones sobre la manera en que debe llevarse a cabo tal manifestación, no puede aceptarse que exista el derecho de quienes lo conciben de una forma determinada a integrarse con quienes lo entienden de otra diferente cuando no haya acuerdo sobre esa integración» (FJ 6. $\left.{ }^{\circ}\right)$.

Esta STS de 2 de junio de 2003 tuvo efecto lógico e inmediato en posteriores SSTSJPV. Así, la STSJPV de 24 de octubre de 2003 en la que, con mención expresa al cambio de criterio operado, se señala que «las consecuencias relevantes de la anterior doctrina (...) son tres:

En primer lugar, que el desarrollo del Alarde constituye ejercicio del derecho de reunión [para las dos partes que pretenden participar en el mismo bajo su distinta y particular concepción].

En segundo lugar, que siendo ejercicio del derecho de reunión por quienes conciben dicho acto de forma radicalmente incompatible, no cabe reconocer el derecho de uno de ellos a integrarse en el otro si no hay acuerdo sobre dicha integración, sin que jueguen en ello consideraciones de igualdad relevantes desde el momento en el que no intervienen en su organización las corporaciones públicas.

Finalmente, que ante la probable alteración del orden público y de la paz ciudadana que el intento de fusión de ambos grupos puede producir corresponde a la Administración el ejercicio de las potestades que tienen conferidas por la LO 9/1983 de 15 de julio para modalizar el ejercicio del derecho alterando las circunstancias de tiempo o lugar en lo mínimo indispensable para conjurar dichos peligros y para satisfacer en su mayor grado el derecho de manifestación de cada uno de los grupos, y finalmente durante el desarrollo de los actos, el ejercicio de sus potestades de policía en orden al mantenimiento del orden y la paz. social» (FJ 3..$^{\circ}$.

\section{EN CUANTO A LA ACTUACIÓN POLICIAL}

Por lo que atañe a la actuación policial que la STSPV consideró discriminatoria, el TS disiente igualmente por entender que ésta no sólo no se desentendió de la solicitud de protección efectuada por el AI, sino que su intervención evitó conductas y sucesos más graves, fue adecuada y proporcionada y tendió a garantizar el ejercicio del derecho fundamental concernido sin pretender la discriminación ni producirla efectivamente (FJ $\left.6 .^{\circ}\right)$. 
E) Síntesis de la doctrina del Tribunal Constitucional sobre el Derecho de Reunión

Según se ha manifestado en los argumentos, tanto la sentencia recurrida en casación, como la STS que la anula, se remiten a doctrina del TC en apoyo de sus tesis. En la medida en que ambas son abiertamente contradictorias, creemos que es conveniente tratar de sintetizar, de un modo ordenado, los pronunciamientos que sobre el derecho de reunión en lugares de tránsito público ha realizado el $\mathrm{TC}^{16}$ :

a) El derecho de reunión es «una manifestación colectiva de la libertad de expresión ejercitada a través de una asociación transitoria de personas, que opera a modo de técnica instrumental puesta al servicio del intercambio o exposición de ideas, la defensa de intereses o la publicidad de problemas y reivindicaciones». Un derecho que es «individual en cuanto a sus titulares y colectivo en su ejercicio» y que históricamente surge como derecho autónomo intermedio entre los de libre expresión y asociación con los que sigue manteniendo «íntima conexión doctrinal» tal y como se refleja en su propia conceptuación.

b) Cuatro son los elementos que configuran este derecho:

1) Subjetivo: Agrupación de personas caracterizada de modo esencial por ser una «concurrencia concertada» en la que se da cierto grado de vinculación de cada uno de los participantes con los demás. Desde esta consideración, no constituye elemento subjetivo la mera aglomeración o confluencia casual de personas en un determinado espacio físico puesto que es preciso que exista «concierto mutuo para concurrir, el saberse participantes en una reunión».

2) Objetivo: Lugar de celebración ${ }^{17}$.

3) Temporal: Duración transitoria.

4) Finalista: En este punto debe distinguirse entre fin como elemento interno y parte del contenido esencial del derecho y la finalidad de la reunión como elemento externo. Así las cosas, la licitud de esta última «funciona como condición legitimadora del ejercicio del derecho», mas no como contenido de éste, de lo que se concluye que no cabe canalizar por vía del derecho de reunión cualquier actividad lícita so pena de desnaturalizar el derecho a través de una

${ }^{16}$ Sin ánimo agotador, cabe citar como sentencias más relevantes, las que siguen: STC (Sala 1. ${ }^{\text {a) }}$ 85/1988, de 28 de abril de 1988; recurso núm. 942/1987; BOE 128/1988, de 28 de mayo de 1988. STC (Sala 2. ${ }^{\text {a) }}$ 66/1995, de 8 de mayo de 1995; recurso núm. 1693/1992; BOE 140/1995, de 13 junio 1995.

${ }^{17}$ Debe tenerse en cuenta que, aunque el objeto de este estudio obliga a circunscribir el derecho de reunión al producido en lugares de tránsito público, en realidad cabe hablar de dos clases de reuniones atendiendo al lugar en el que se celebran, siendo distinto el régimen de intervención administrativa aplicable en uno y otro caso. 
inversión de los términos relativos a su finalidad. En síntesis: «es la licitud del fin la que legitima la reunión y no el derecho de reunión con fin lícito el que legaliza, por su sola invocación, la actividad a través de la cual se cumple dicho fin».

c) Los elementos subjetivo y objetivo del derecho de reunión hacen que éste adquiera una dimensión de singular relieve como «cauce del principio democrático participativo» en un Estado social y democrático de Derecho. Desde este punto de vista, el derecho del art. $21 \mathrm{CE}$ es «para muchos grupos sociales (...) uno de los pocos medios de los que disponen para poder expresar públicamente sus ideas y reivindicaciones».

d) Como cualquier otro derecho, el de reunión no es un derecho ilimitado o absoluto y exige conciliar su ejercicio con la protección de derechos y bienes de terceras personas. Esta circunstancia explica la previsión de un régimen de intervención administrativa que, en cualquier caso, no tiene carácter autorizatorio. En este sentido, la obligación de comunicación previa a la autoridad gubernativa no implica el deber de obtener autorización, por cuanto el ejercicio del derecho «se impone por su eficacia inmediata y directa sin que pueda conceptuarse como un derecho de configuración legal» ${ }^{18}$.

e) De igual modo, la potestad administrativa que permite a la autoridad gubernativa el establecimiento de modificaciones y, en su caso, la prohibición de ejercicio del derecho, «no es reconducible a ningún género de manifestación de autotutela», puesto que cualquier actuación administrativa en esa dirección es revisable jurisdiccionalmente con una inmediatez que encuentra reflejo tanto en el plazo del que dispone el órgano administrativo para dictar resolución, como en «el mecanismo especialmente acelerado de control judicial de la misma».

f) El límite del derecho de reunión conforme al art. 21.2 CE exige que cualquier modificación o prohibición de éste se apoye en «razones fundadas de alteración del orden público», expresión que merece, a su vez, ciertas precisiones:

— La existencia de «razones fundadas» impide que sea suficiente «la mera sospecha o la posibilidad de que ésta produzca esa altera-

${ }^{18}$ En Derecho Administrativo esta figura suele conocerse como «comunicación previa con reserva de oposición», que SANTAMARÍA PASTOR caracteriza como «modalidad aligerada de la técnica autorizatoria», consistente en que se otorga a la Administración la potestad de comprobar la legalidad de los términos de la comunicación y su ajuste a los intereses públicos, pudiendo formular en su caso un mandato prohibitivo o condiciones para su realización, de suerte que, transcurrido el plazo sin respuesta administrativa, el particular puede emprender la actividad proyectada. SANTAMARÍA PAStor, Juan Alfonso, Principios de Dere-

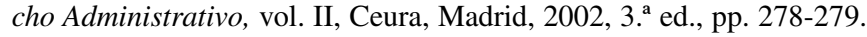


ción», sino que exige que la autoridad gubernativa cuente con «datos objetivos suficientes, derivados de las circunstancias de hecho concurrentes en cada caso, a partir de los que cualquier persona en una situación normal pueda llegar racionalmente a la conclusión, a través de un proceso lógico basado en criterios de experiencia, que la concentración producirá con toda certeza el referido desorden público». En cualquier caso, una interpretación sistemática del precepto constitucional lleva a que las eventuales dudas sobre la producción de estos efectos deban ser resueltas mediante la necesaria aplicación del principio «favor libertatis».

- De la locución «razones fundadas», derivan tres consecuencias relevantes: a) la resolución gubernativa deberá estar motivada; b) el que deban ser fundadas exige que se aporten las razones que han llevado a la conclusión de que, si se celebra la reunión en los términos en los que está prevista, se producirá la alteración del orden público proscrita; $\mathrm{y}, \mathrm{c})$ de igual modo, debe justificarse la imposibilidad de adoptar las medidas preventivas necesarias para conjurar esos peligros y permitir el efectivo ejercicio del derecho fundamental.

— El orden público al que se refiere el art. 21.2 CE no remite a un concepto genérico de orden público, sino «al orden público con peligro para personas o bienes», de suerte que la «situación de peligro» se incorpora a la noción no como elemento adjetivo o externo, sino como su elemento sustantivo y definidor que, en cuanto tal, debe ser analizado «en el contexto del precepto constitucional del que forma parte, es decir, como límite del derecho fundamental de reunión en lugares de tránsito público». Desde esta premisa, el orden público «se refiere a una situación de hecho, el mantenimiento del orden en sentido material en lugares de tránsito público, no al orden como sinónimo de respeto a los principios y valores jurídicos y metajurídicos que están en la base de la convivencia social y son fundamento del orden social, económico y político». De ahí la imposibilidad de que los poderes públicos apliquen criterios de oportunidad política o juicios basados en el sistema de valores que fundan el orden social en un momento histórico determinado lo que, a la postre, impide cualquier discriminación motivada en el contenido de los mensajes que los promotores pretendan transmitir y siempre que aquéllos no contravengan la legalidad.

- La afectación del orden público debe ser con peligro para las personas y bienes, "entendiendo por tal desorden material el que impide el normal desarrollo de la convivencia ciudadana en aspectos que afectan a la integridad física o moral de personas o a la integridad de bienes públicos o privados». De este modo, no cabe 
la limitación del derecho basada en cualquier tipo de alteración del normal funcionamiento de la vida colectiva, sino sólo aquella que implique un desorden externo con riesgo para la integridad de las personas y bienes. Dicho esto, debe también precisarse que «ese peligro no es sinónimo de utilización de la violencia» por parte de quienes participan en las concentraciones, ya que en este caso, no cabría otra solución que la prohibición de la convocatoria correspondiente, «puesto que se trataría de una acción ajena o no integrada en el referido derecho».

— El art. 21.2 CE «no delimita el contenido del derecho de reunión, sino que establece un límite a su ejercicio», y otorga a los poderes públicos una facultad (la de modificación o, en su caso, prohibición) que en su ejercicio debe estar guiada por el principio de proporcionalidad. Teniendo en cuenta que ese límite del 21.2 CE debe tener un contenido concreto, «deberá concluirse que en su ámbito se incluyen los peligros para personas o bienes derivados de las acciones violentas que puedan derivarse de la celebración pacífica de la concentración, ya sea porque la misma cree situaciones que provoquen directamente esos peligros, ya porque imposibilite la realización de actividades tendentes a evitar o a paliar los citados peligros» ${ }^{19}$.

g) Por lo que respecta a la concreta facultad de prohibición del ejercicio del derecho de reunión, se subraya la necesidad de que medida tan drástica esté sometida a un juicio de proporcionalidad de suerte que sólo será constitucionalmente legítima en caso de que no existan otros medios de preservar el orden público. Dicho juicio de proporcionalidad deberá reunir tres requisitos o condiciones: 1) aptitud de la medida para alcanzar el objetivo propuesto (salvaguarda del orden público sin peligro para personas y bienes); 2) necesidad de la medida, entendida como inexistencia de medida alternativa más moderada para el logro del objetivo con igual eficacia; 3) proporción en sentido estricto, esto es, adecuación y equilibrio «por derivarse de ella más beneficios o ventajas para el interés general que perjuicios sobre otros bienes o valores en conflicto».

${ }^{19} \mathrm{El}$ entrecomillado corresponde al FJ $3 .^{\circ}$ de la STC 66/1995 de 8 de mayo (cit.), que contó con un Voto particular formulado por el Magistrado GonZÁLEZ CAMPOS quien, en relación con el párrafo trascrito, subraya que la sentencia debería haber concretado más uno y otro supuesto «pues es evidente que no conduce al mismo resultado que el peligro para las personas y bienes derivado de la previsible alteración del orden público sea entendido como un peligro directo o sólo indirecto». Desde esta posición, el Magistrado entiende que incluir los riesgos para las personas y bienes que puedan producirse de un modo indirecto o eventual implica «una discutible ampliación del límite establecido en el art. 21.2 CE» que, aun aceptada, requiere una mayor exigencia a la autoridad gubernativa sobre la justificación de la imposibilidad de adoptar medidas preventivas. 
h) La facultad de modificación permite a la autoridad gubernativa la alteración de fecha, lugar o duración de la reunión a celebrar. No obstante, esta facultad no es enteramente discrecional, sino que viene condicionada por la programación dada por los promotores. Particularmente importante es el elemento objetivo (lugar de celebración) del derecho de reunión ya que su elección por parte de los promotores «está íntimamente relacionado con el objetivo de publicidad de las opiniones y reivindicaciones» de aquellos hasta el punto de que «en ciertos tipos de concentraciones el lugar de celebración es para los organizadores la condición necesaria para poder ejercer su derecho de reunión en lugares de tránsito público, puesto que del espacio físico en el que se desenvuelve la reunión depende que el mensaje que se quiere transmitir llegue directamente a sus destinatarios principales».

\section{F) Nuestra crítica a la STS de 2 de junio de 2003}

A nuestro entender, y sin negar validez a la argumentación de la STS, el entronque de los Alardes en el derecho de reunión resulta forzado. En primer lugar, el que «unos y otros» se acogieran a las normas que regulan el mencionado derecho o el que la demanda se construyera sobre él no es un dato suficientemente decisivo. Hemos tenido ocasión de comprobar que los procesos originados por los Alardes están plagados de ardides de todo tipo, mediante los cuales las partes tratan de eludir doctrina jurisprudencial según convenga a sus intereses. De igual modo, se acogen a cauces procesales que no siempre resultan los idóneos, tal y como se ha constatado en alguna de las sentencias a las que hemos aludido y que declaran la inadmisibilidad de ciertos recursos.

Tampoco estamos de acuerdo en que, desde un punto de vista de derecho sustantivo, los actos comprendidos en los Alardes puedan considerarse como ejercicio del derecho de reunión, aunque debemos convenir que en el AI se da una nota reivindicativa que puede inducir a equívocos. No puede ponerse en duda que estamos ante dos concepciones distintas de una fiesta; igualmente incuestionable es que el devenir de los acontecimientos prueba que ambas concepciones son irreconciliables y que las Administraciones públicas concernidas se han mostrado incapaces de acercar posturas. Ahora bien, cuestión distinta es que el dislate producido por todos esos factores encuentre una solución de conveniencia que, de algún modo, implique el entendimiento extensivo de un derecho fundamental con el fin de poder hacer aplicable el régimen jurídico de éste, tratando de conseguir así un eventual «efecto pacificador».

Se dice por parte del TS que «grupos distintos de personas se reunieron pacíficamente y sin armas, pues las que portaban únicamente tenían el sentido de completar el atuendo y de servir para salvas, con el propósito de manifestar públicamente las ideas que les animan entre las que se incluyen, 
junto a la conmemoración de un acontecimiento histórico y la renovación del voto a la Virgen de Guadalupe, las que se refieren al acto mismo del Alarde, pues sobre esa celebración de carácter cívico y religioso se mantienen dos concepciones diferentes en torno a la participación de la mujer». Esta visión de la realidad permite al TS derivar que confluyen los cuatro elementos que configuran el derecho de reunión y que han quedado expuestos en líneas precedentes. Una conclusión, a nuestro entender, más que cuestionable:

a) En cuanto al elemento subjetivo, parece claro que estamos ante una agrupación de personas, «pacífica y sin armas». La mera alusión a que las que portaban formaban parte del atuendo no deja de parecernos chocante y, en todo caso, es un dato cuya aparente irrelevancia puede ser engañosa (volveremos sobre ello al hablar del elemento finalista). Sin embargo, la cuestión no es tanto que se dé una agrupación de personas como el que haya «concurrencia concertada», esto es, el que los participantes se sepan en una reunión. ¿Los participantes en el Alarde «se saben» en una reunión o, por el contrario, en una fiesta popular? Ciertamente los acontecimientos que se han ido produciendo en estos años pueden haber alterado la percepción, la propia toma de conciencia de los integrantes de los distintos Alardes sobre el significado del acto en el que participan, ideologizándolo total o parcialmente y sumando componentes de «libertad de expresión» inexistentes en tiempos anteriores. Por otro lado, también debe admitirse que, sobre todo en el AI, se da un importante ingrediente reivindicativo en cuanto a la igualdad de derechos de la mujer que, además, encuentra ligazón con ciertas asociaciones y grupos formalmente constituidos. Dichos factores tal vez permitan deducir que se cumple un elemento subjetivo que, de cualquier modo, no termina de encajar plenamente en cuanto nos resulta dudoso que todos los vecinos participantes de los eventos acudan entendiendo que éstos van más allá de un mero festejo local.

b) El elemento objetivo consistente en el lugar de reunión puede parecer absolutamente evidente, pero de igual manera, presenta algunas dificultades. Una reunión en lugares de tránsito público no elige cualquier tipo de ubicación en la medida en que el emplazamiento se enlaza con el mensaje y/o con la difusión que se quiere dar a éste. No obstante, el hecho de que el Alarde transcurra por los «centros neurálgicos» de una determinado término municipal no tiene una significación especial o, si se prefiere, diferencial. Todas las fiestas locales en cuyo programa se incluyen paseos de comparsas, grupos vecinales o «procesiones» de cualquier tipo transitan por los principales lugares del Municipio. Es más, cualquier actividad programada en fiestas se lleva a cabo, casi por definición, en el núcleo principal de un pueblo, no extramuros de él. 
c) El elemento temporal - duración transitoria - no plantea en principio problemas, ni siquiera por su carácter periódico. Puede decirse que no son las más frecuentes, pero debemos admitir que determinadas manifestaciones se producen invariablemente en determinada fecha cada año y todos los años. En cualquier caso, el ingrediente temporal es, desde nuestro punto de vista, el menos revelador y en el supuesto que nos ocupa cabe considerarlo coincidente con la temporalidad propia de toda fiesta popular que, de la misma manera, se celebra también en unas fechas predeterminadas y con carácter transitorio.

d) La divergencia principal se produce, sin duda, en el elemento finalista que, a nuestro juicio, no fue debidamente considerado en la STS. Señalábamos antes que la doctrina del TC distingue entre fin como componente interno y parte del contenido esencial del derecho de reunión y finalidad lícita de éste, que actúa externamente y como condición legitimadora de su ejercicio.

Por aportar todos los detalles, diremos que esta distinción se efectuó en STC 85/1988, de 28 de abril (cit.), en la que se resolvió un recurso de amparo interpuesto en relación con una resolución de la Delegación del Gobierno de Asturias que denegaba la solicitud para la celebración de cuestaciones públicas. En la sentencia se afirmaba que las cuestaciones públicas no constituyen ejercicio del derecho de reunión por no concurrir en ellas ni el elemento subjetivo de «concurrencia concertada», ni el finalista, realizando en este punto la distinción a la que nos venimos refiriendo; asimismo se recuerda que las cuestaciones están reguladas en disposiciones específicas que prevén, a su vez, un concreto régimen de intervención administrativa distinto necesariamente del propio de un derecho fundamental como el de reunión.

Pues bien, el TS «despacha» el análisis de este extremo indicando que «es clara la diferencia entre el Alarde y otras agrupaciones transitorias de personas que no son expresión del derecho de reunión como las que pretenden cuestaciones mediante mesas petitorias que menciona la Sala de instancia». Este argumento, tomado en sus propios términos, no puede compartirse por cuanto la Sala de lo Contencioso Administrativo del TSJPV (Sala de instancia) en ningún momento asimiló el Alarde a las cuestaciones públicas, limitándose a traer doctrina constitucional al supuesto enjuiciado y aportando, sin más pretensiones, los datos relativos a la STC en la que se basaba. La Sala, en jurisprudencia reiterada, ha entendido que el Alarde constituye en esencia un espectáculo público en el que confluyen aspectos muy variados - festivos, religiosos, históricos, de participación cívica...- y que, en atención a esta naturaleza, se rige por la normativa sectorial aplicable a estos eventos. Por lo demás, el empleo de este argumento podría igualmente jugar en contra de la STS, en la medida en que ésta se apoya en la STC 42/2000, de 14 de febrero, por la que se estima un recurso de amparo contra ciertas resoluciones administrativas que imponían multas por interrupción del tráfico al participante en una manifestación de trabajadores debidamente comunicada; supuesto que tampoco es asimilable en modo alguno al de los Alardes. 
La STS que ahora comentamos no entra, en realidad, en el análisis de los elementos conformadores del derecho de reunión, sino que, por lo que se desprende de la lectura de los Fundamentos Jurídicos, los entiende concurrentes sin mayor precisión por apreciarse un «claro propósito participativo (...), algo que caracteriza el ejercicio típico de reunión y manifestación y no lo transforma en innominada facultad de participación cívica que aprecia la sentencia de instancia».

Que el derecho de reunión posee un carácter de cauce democrático participativo es, desde luego, irrebatible y así ha sido subrayado por el TC. Sin embargo, no toda expresión de participación ciudadana constituye derecho de reunión so pena, como decíamos, de desnaturalización del derecho, extendiendo su ámbito más allá de lo admisible. Cualquier finalidad lícita no desemboca en elemento finalista del derecho de reunión, sino que actúa con externidad a él. En este sentido, creemos que el TS confunde el aspecto participativo que existe en los Alardes otorgándole una vertiente que no posee, por más que, en efecto, los conflictos tengan su origen en dos concepciones distintas de ellos. En tal sentido, no estamos de acuerdo en que nos hallemos ante «distintas concepciones sobre la manera en que debe llevarse a cabo tal manifestación», considerando a priori que el Alarde es manifestación por su rasgo de participación.

Los mismos detalles externos de los participantes, con atuendos de época, compañías en un desfile de corte histórico-militar (que crípticamente sirven al TS para concluir que es una reunión «pacífica») dan muestra de que los intervinientes son, antes de nada, vecinos en una fiesta y no integrantes de una manifestación.

Por lo demás, no encontramos el sentido que se quiere dar a la expresión «innominada facultad de participación cívica», locución que sirve de crítica a la STSJPV. La participación, ligada comúnmente a la cláusula de Estado Democrático, aparece «nominada» en el texto constitucional sólo en ciertos casos y, por lo que respecta al art. 9.2 CE, con total amplitud incluyendo la de «todos los ciudadanos en la vida política, económica, cultural y social».

\section{La respuesta judicial al último conflicto: sentencia del Tribunal Superior de Justicia del País Vasco de 21 de junio de 2005}

\section{A) Objeto del proceso}

Se impugna en el presente caso la Resolución del Director de Seguridad Ciudadana del Departamento de Interior del Gobierno Vasco de 10 de junio de 2005, por la que se dispone sobre horarios e itinerarios de los Alardes de San Marcial de Irún, modificando parcialmente los correspondientes tanto al AT (recurrente en el proceso) como al AI.

Ha de ponerse de manifiesto que los promotores del AT solicitaron del Ayuntamiento de Irún la autorización para su desfile al amparo de la Ley del 
Parlamento Vasco 4/1995, de 10 de noviembre, de Espectáculos públicos; autorización que fue otorgada por Resolución del indicado Ayuntamiento de 17 de febrero de 2005 y debidamente comunicada por éste a la autoridad autonómica. Por el contrario, el AI comunicó al gobierno autonómico el plan de su convocatoria en cumplimiento del régimen jurídico aplicable al ejercicio del derecho de reunión y que, como es sabido, implica el ejercicio de ciertas potestades públicas de intervención.

Respecto a las distintas vías empleadas — cuestión que, como se verá, suscitó cierta dificultad procesal-, sólo cabe pensar que estamos ante un nuevo intento «tramposo» de eludir la legalidad que, conforme a la STS de 2 de junio de 2003, es aplicable a los Alardes. Al margen de la crítica que esta sentencia pueda merecer, lo cierto es que sienta una doctrina clara sobre la naturaleza de esta celebración y en tal medida, resulta cuando menos sorprendente que el AT haga oídos sordos a dicho pronunciamiento canalizando una solicitud de autorización al amparo de la normativa sectorial de espectáculos públicos ${ }^{20}$.

Más insólita resulta aún la postura del Ayuntamiento de Irún que, en respuesta a la comunicación de manifestación efectuada por la autoridad autonómica competente, informa de la autorización para la celebración del Alarde de San Marcial, sus horarios y emplazamientos aludiendo a «que el Tribunal Superior de Justicia del País Vasco mediante la correspondiente sentencia ya ha fallado que la conmemoración del Alarde no tiene amparo en el derecho de reunión o manifestación», que en todo caso tal conmemoración está sujeta a la regulación sobre espectáculos públicos, terminando su informe del siguiente modo: «... parece que el acto comunicado es expresión de la celebración de un acto de Alarde que parte, como premisa falsa, de la cobertura por el derecho de manifestación o reunión según se ha dicho antes».

${ }^{20}$ A nuestro juicio el carácter tendencioso de la petición de autorización municipal queda en evidencia en las propias alegaciones del AT al formular el recurso y que el FJ $1 .^{\circ}$ STSJPV de 21 de junio de 2005 sintetiza del siguiente modo: «(...) b) La resolución recurrida afecta ilícitamente a la determinación sobre el orden público llevada a cabo por la autorización administrativa municipal concedida a favor de la Asociación recurrente. La celebración de la manifestación comunicada el 8 de junio de 2005 por la "Asociación A. P. A. A.” [AI] para su celebración el mismo día 30 de junio de 2005, responde a una concepción del Acto del Alarde de San Marcial opuesta al sostenido por la ahora recurrente y se presenta con un carácter reivindicativo y reaccional respecto del mismo. Por lo que al coincidir parcialmente en horarios y recorridos, incide gravemente en el orden público previamente establecido por la resolución municipal dictada al amparo de la Ley del Parlamento Vasco 4/1995, de 10 de noviembre, de espectáculos públicos» (la negrita es nuestra).

Lo que parece deducirse de esta alegación es que la petición de autorización municipal por parte de los promotores del AT trató de «preconstituir orden público», si es que cabe tal expresión. 
El contenido del informe municipal sólo puede producir perplejidad y, desde luego, no puede tener su justificación en un eventual desconocimiento de la doctrina del TS sentada dos años antes. Antes bien, estamos ante una omisión consciente y puede decirse que hasta recalcitrante en su empeño de dar cobertura jurídica a una de las partes implicadas. Una actitud que, a nuestro juicio, no es admisible en una Administración Pública que, conforme al art. 103.1 CE, debe servir con objetividad los intereses generales y actuar con sometimiento pleno a la ley y al Derecho.

\section{B) Legitimación Activa y art. 122.1 LJCA.}

La Administración demandada opone la inadmisibilidad del recurso por falta de legitimación activa de la recurrente (art. 69.b) in fine LJCA), por entender que estando ante un procedimiento especial de protección de derechos fundamentales de la persona, procede aplicar el art. 122.1 LJCA, conforme al cual sólo los «promotores» están legitimados para la interposición del recurso ${ }^{21}$.

Dicha alegación se funda en que la petición original de la Asociación recurrente, lejos de enmarcarse en el ejercicio del derecho de reunión, encuentra el título jurídico que le sirve de fundamento en la autorización municipal para celebrar un espectáculo público, invocando asimismo la interpretación dada por el mismo Tribunal en Auto de 13 de septiembre de 2002.

Por lo que atañe a este último argumento, la Sala recuerda las diferencias entre el caso que dio lugar al precitado Auto y el que ahora se resuelve. En efecto, en aquel proceso jurisdiccional, el TSJPV vino a negar legitimación activa a la Delegación del Gobierno en la Comunidad Autónoma Vasca para recurrir la inactividad del Gobierno Vasco al no prohibir una manifestación a celebrar en Bilbao con el fin de «protestar contra las actuaciones realizadas por el Juzgado núm. 5 de la Audiencia Nacional y por el Congreso de los Diputados». Ante la petición de una medida cautelar de suspensión de la manifestación con base en el supuesto interés legítimo de «salvaguardar el cumplimiento de las resoluciones judiciales», la Sala apreció la falta de legitimación activa de la Delegación del Gobierno «a partir de una doble denotación jurídico-procesal» a la que se remite en el presente caso:

— «El art. 11.1 de la Ley Orgánica 9/1983, de 15 de julio, Reguladora del derecho de reunión, en relación con el art. 122.1 de la Ley Juris-

${ }^{21}$ La dicción literal del artículo establece: «En el caso de prohibición o propuesta de modificación de reuniones previstas en la Ley Orgánica Reguladora del Derecho de Reunión que no sean aceptadas por los promotores, éstos podrán interponer recurso contencioso-administrativo ante el tribunal competente (...) dentro de las 48 horas siguientes a la notificación de la prohibición o modificación». 
diccional 29/1998, atribuye la legitimación para solicitar el control jurisdiccional de la actuación administrativa en el ámbito de dicho procedimiento jurisdiccional especial a los organizadores o promotores de la manifestación afectada; y, exclusivamente, frente a la decisión gubernativa de prohibición o de propuesta de modificación en la forma de ejercicio de derecho fundamental. Por lo que,

- la determinación del título jurídico (derecho o interés legítimo en relación con la prohibición o la propuesta de modificación de la reunión o manifestación, sobre el que la parte recurrente funda la legitimación para el ejercicio de las pretensiones procesales, define un requisito indispensable para la válida constitución de la relación jurídico procesal» (FJ 2..$^{\circ}$.

En segundo lugar, en cuanto al título jurídico que sirve de base a la pretensión y su eventual discordancia con la vía procesal seguida, el Tribunal estima que, en aplicación de la doctrina jurisprudencial establecida en la STS de 2 de junio de 2003, el Alarde es asimilable al ejercicio del derecho reconocido en el art. $21 \mathrm{CE}$. Y hace notar que la Resolución administrativa impugnada es resultado de la acumulación y resolución en un mismo procedimiento administrativo (art. 73 LRJAP $^{22}$ ) de dos intervenciones administrativas: la primera, incoada a instancia del AI; la segunda, seguida de oficio tras la comunicación municipal del otorgamiento de la autorización al AT.

Así las cosas, «la autoridad gubernativa ha tenido en todo momento a ambas asociaciones organizadoras de cada una de las distintas formas de Alarde (...) como promotoras de unos actos a desarrollar en lugares de tránsito público del término municipal de Irún», siendo obligado «reconocer la evidencia del título jurídico (interés legítimo como sujeto pasivo de la situación de gravamen creada unilateralmente por la resolución de la autoridad gubernativa) que dota de legitimación activa a la recurrente (...)» (FJ 2. $\left.{ }^{\circ}\right)$.

C) Los argumentos de la Asociación recurrente y la respuesta judicial a éstos

La parte actora sostiene su pretensión anulatoria en tres motivos de impugnación, uno de los cuales ha sido ya comentado en líneas precedentes (véase nota al pie núm. 20).

${ }^{22}$ Según este artículo «el órgano administrativo que inicie o tramite un procedimiento, cualquiera que haya sido la forma de su iniciación, podrá disponer su acumulación a otros con los que guarde identidad sustancial o intima conexión», sin que quepa recurso alguno contra el acuerdo de acumulación. 
Se arguye en primer término, que la resolución recurrida ha sido dictada sin audiencia previa a la Asociación promotora del AT, trámite que, sin embargo, y como subraya la sentencia, no está previsto en el procedimiento especial establecido en la LODR, razón por la cual se rechaza el argumento.

Debe señalarse que, considerando que la resolución administrativa no resulta de un procedimiento administrativo común, la inexistencia de un trámite de audiencia legalmente establecido no determina una menor garantía para los ciudadanos ${ }^{23}$ (cuestión que podría calificarse de alarmante estando en presencia de un derecho fundamental): la LODR dedica cuatro artículos (del 8 al 11) a las «reuniones en lugares de tránsito público y manifestaciones», preceptos que se ciñen a la obligación de comunicación a la autoridad gubernativa su contenido, la notificación por parte de ésta al Ayuntamiento en que la reunión haya de celebrarse para que informe sobre las circunstancias del recorrido propuesto ${ }^{24}$, las causas que permiten la introducción de modificaciones (o en su caso, prohibición) por parte de la instancia pública competente $\mathrm{y}$, finalmente, el cauce jurisdiccional y plazos de acceso a éste para recurrir dicha resolución modificativa o prohibitiva de la reunión comunicada ${ }^{25}$.

Dicho esto, la garantía del derecho no se halla tanto en el propio procedimiento administrativo - sumamente lacónico — como en la apertura inmediata de la vía judicial; hecho este «que disipa cualquier situación de indefensión material» (FJ 3. $\left.{ }^{\circ}\right)$.

La misma suerte que la anterior alegación corre la denuncia de que la resolución administrativa incurre en desviación de poder. Alegación, en todo caso, deficientemente formulada, en cuanto sólo se predica de parte de la resolución (la relativa a tiempos del recorrido) y no de la que afecta al AI.

${ }^{23}$ La propia CE, en su art. 105.3, no contempla el trámite de audiencia como elemento insoslayable de todo procedimiento administrativo. En este sentido establece que la ley regulará «el procedimiento a través del cual deben producirse los actos administrativos, garantizando, cuando proceda, la audiencia del interesado».

${ }^{24}$ Esta previsión del art. 9.2 fue incorporada por LO 9/1999, de 21 de abril (BOE 96/1999, de 22 de abril) de modificación de la LO 9/1983, para «hacer posible que los municipios afectados por el ejercicio de los derechos de reunión y manifestación estén informados y hagan patente su opinión ante la autoridad gubernativa, sin que ello suponga la modificación de las condiciones y plazos para el ejercicio de dichos derechos, de acuerdo con el principio de garantizar a estas entidades locales su derecho a participar en todos aquellos asuntos que afecten a su ámbito de interés, aun cuando sí se acomoda al nuevo trámite el plazo de que dispone la autoridad gubernativa para prohibir o proponer modificaciones» (Exposición de Motivos LO 9/1999).

${ }^{25}$ Esta regulación está en plena consonancia con el art. 21.2 CE, en virtud del cual, «En los casos de reuniones en lugares de tránsito público y manifestaciones se dará comunicación previa a la autoridad, que sólo podrá prohibirlas cuando existan razones fundadas de alteración del orden público, con peligro para personas o bienes». 
Entiende la actora (AT) que la intervención gubernativa subvierte los límites del art. 10 LO 9/1983, por cuanto en lugar de estar basada en «razones fundadas de que puedan producirse alteraciones de orden público con peligro para personas y bienes», lo hace dando prioridad a la reivindicación de una política de igualdad.

Con el fin de comprender mejor el sentido del argumento, conviene hacer mención al caso resuelto por STSJPV de 24 de octubre de $2003^{26}$. Se impugnaba igualmente una Resolución del Director de Seguridad Ciudadana del Departamento de Interior del Gobierno Vasco en la que, a diferencia del supuesto que nos ocupa ahora, se determinó que en el Alarde de Hondarribia la AT desfilara «sin solución de continuidad, inmediatamente posterior a la C. J. [AI]». En el examen del fondo del asunto, el Tribunal estimó disconforme a derecho el acto recurrido al apreciar que se producía una vulneración del derecho de reunión de la recurrente que no podía «verse forzada contra su voluntad a desfilar junto a quienes conciben el Alarde en términos que, por las razones que sólo a ellos incumben, no están dispuestos a aceptar». Y prosigue con la siguiente consideración en la que, sin duda, encuentra su apoyo la alegación de la que estamos hablando:

«Es contraria a derecho además, porque desde la necesaria congruencia entre lo resuelto y la finalidad perseguida de garantizar la seguridad, no guarda la debida adecuación, pues la proximidad de ambos grupos sin solución de continuidad favorece el enfrentamiento según enseña una larga experiencia, por lo que en términos de pura razonabilidad no es admisible y evidencia que en realidad la Administración, cierto que inducida a ello por la doctrina de esta Sala, pretende más bien satisfacer un supuesto derecho a la igualdad de quienes quieren participar en el Alarde con una doble función de las mujeres que no aceptan los convocantes, incurriendo por ello en desviación de poder».

En síntesis: teniendo en cuenta que la posibilidad de prohibición o modificación del ejercicio del derecho de reunión únicamente cabe por remisión a las razones de seguridad contenidas en los arts. 21.2 CE y 10 LODR, la búsqueda de finalidades distintas (satisfacción del derecho a la igualdad) mediante esta potestad administrativa de intervención incurre en un vicio — la desviación de poder- determinante de la anulación del acto (art. 63.1 LRJAP).

A vista de este pronunciamiento, el intento de lograr un fallo en el mismo sentido y sustentado en igual argumentación era lógico, teniendo en cuenta, además, los términos del FJ 5. ${ }^{\circ}$ de la Resolución de 10 de junio de 2005, aquí recurrida:

${ }^{26}$ STSJPV (Sala de lo Contencioso-administrativo; Sección 2. a), núm. 783/2003, de 24 de octubre de 2003; recurso núm. 2266/2000; EDJ 2003/156188. 
«Clarificada la naturaleza jurídica del acto comunicado por parte del Tribunal Supremo, como expresión del ejercicio de un derecho fundamental, ha de tenerse en cuenta en segundo lugar que los valores que propugna la citada manifestación "Alarde Igualitario" se encuentran en sintonía con los que predica tanto el estatuto de Autonomía en su art. 9, apartado 2, como los contenidos en la recientemente aprobada ley 4/2005 para la igualdad de mujeres y hombres. Principios que informan el sentido de los actos de las instituciones públicas vascas, siendo por ello obligación de los poderes públicos, y por lo tanto el objeto de esta Resolución no sólo no poner obstáculos a esta comunicación de manifestación, sino la de tratar de remover aquellos otros que pudieran darse. Poniendo, en su caso, los medios adecuados para su realización efectiva, garantizando y priorizando sobre cualquier otro acto similar la pretensión formulada por los comunicantes de realizar una manifestación para "reclamar la verdadera y efectiva igualdad entre hombres y mujeres en el principal rito de afirmación colectiva de Irún”.

Por ello, se hace necesario, además de regular los términos en los que debe celebrarse la manifestación objeto de esta Resolución, hacer llegar a los organizadores del acto denominado "Alarde Tradicional" estas circunstancias, para que adapten sus actos programados en función de las incidencias y repercusiones que la concurrencia de ambos pudiera tener».

No obstante, lo cierto es que la Resolución impugnada motiva la introducción de modificaciones en razones de seguridad que encuentran apoyo en un informe policial. De él se desprende que la coincidencia parcial de espacios y tiempos entre ambas convocatorias puede ocasionar «graves incidencias de orden público» con riesgo para personas y bienes, y más atendiendo al considerable número de personas que los actos congregan. Motivos que encuentran reflejo en el FJ 6..$^{\circ}$ de la Resolución:

«... considerando los antecedentes de años anteriores, la polémica, los incidentes ocurridos y el carácter masivo de la participación en los diversos actos, se hace preciso disponer lo necesario para garantizar que la celebración de los mismos resulte compatible con las exigencias de la convivencia democrática y el orden pacífico ciudadano, minimizando el riesgo para los participantes, tanto del acto "Alarde Tradicional" como de la manifestación comunicada como "Alarde igualitario", salvaguardando la efectiva protección de las libertades y del derecho de reunión y manifestación».

La STSJPV, recordando que el Alarde ha sido fuente permanente de altercados, tiene como «notorio» que es precisamente el abundante despliegue policial el que ha neutralizado los riesgos verificados en ediciones anteriores, evitando alteraciones de orden público que, por lo demás, son nuevamente previsibles.

Por lo referido a la invocación que la resolución impugnada realiza al art. 9.2 CE y la eventual desviación de poder que ésta pudiere contener, se señala que ésta «queda limitada a motivar, a mayor abundamiento una opción 
que, nuclearmente, se funda en la más efectiva preservación del ejercicio del derecho de reunión por ambas Asociaciones promotoras. Por lo que cabe entender que la invocación de la licitud de los objetivos de reclamación de una determinada forma de participación cívica de las mujeres en los actos del Alarde se efectúa a los solos efectos de priorizar el ejercicio de las competencias gubernativas en materia de reunión y manifestación respecto de las competencias municipales en materia de autorización de espectáculos públicos».

Entendemos que del contenido de la Resolución impugnada se sigue que, efectivamente, son razones de orden público las que motivan la modificación parcial de trayectos y horarios efectuada por la autoridad gubernativa. Sin embargo, y aunque compartimos la interpretación de que el argumento «pro igualdad» lo es «a mayor abundamiento», no es tan evidente que la pretensión de «priorizar» se refiera a dar preponderancia a las competencias gubernativas en materia de derecho de reunión sobre las municipales en el ámbito sectorial de espectáculos públicos. Desde nuestro punto de vista, ni la dicción literal del FJ 5. ${ }^{\circ}$ de la Resolución, ni el mismo contexto en el que se hace la afirmación, permiten concluir en esa línea; mas al contrario, parece indicarse que ante actos de un mismo carácter debe prevalecer aquél en el que se propugne la igual participación entre hombres y mujeres ${ }^{27}$ y dicha finalidad, aunque encomiable y legítima, se desmarca de los rigurosos límites a los que se somete la intervención administrativa en este derecho fundamental.

${ }^{27}$ Así parece colegirse de la mención a la Ley del Parlamento Vasco 4/2005, de 18 de febrero (BOPV núm. 42, de 2 de marzo de 2005) para la Igualdad de Mujeres y Hombres. Aunque no se alude explícitamente a artículo alguno, no podemos obviar la intención subyacente en el art. 25 de dicha Ley cuando, bajo el rótulo «Actividades culturales» establece:

«1. Las administraciones públicas vascas, en el ámbito de sus competencias, han de adoptar las medidas necesarias para evitar cualquier discriminación por razón de sexo y para promover un acceso y participación equilibrada de mujeres y hombres en todas las actividades culturales que se desarrollen en el ámbito de la Comunidad Autónoma de Euskadi.

Se prohíbe la organización y realización de actividades culturales en espacios públicos en las que no se permita o se obstaculice la participación de las mujeres en condiciones de igualdad con los hombres.

2. Las administraciones públicas vascas no podrán conceder ningún tipo de ayuda ni sus representantes podrán participar en calidad de tales en ninguna actividad cultural, incluidas las festivas, las artísticas, las deportivas y las realizadas en el ámbito de la normalización lingüística del euskera, que sea discriminatoria por razón de sexo. (...)».

No obstante, y considerando el enlace del Alarde con el derecho de reunión, debe entenderse de aplicación el art. 3.2 («Igualdad de oportunidades») de la misma Ley, según el cual: «Los poderes públicos vascos deben adoptar las medidas oportunas para garantizar el ejercicio efectivo por parte de mujeres y hombres, en condiciones de igualdad, de los derechos políticos, civiles, económicos, sociales y culturales y del resto de derechos fundamentales que puedan ser reconocidos en las normas (...)». 


\section{Consideraciones finales}

El recorrido por la jurisprudencia sobre los Alardes evidencia que ésta se encuentra cargada de aristas, diversidad de planos jurídicos y subterfugios de todo tipo que, de algún modo, han sobredimensionado el conflicto.

La mejor muestra de ello es posiblemente la STS de 2 de junio de 2003 que, considerando el Alarde como expresión del derecho de reunión, termina por dar una solución que, opinamos, es poco convincente y jurídicamente cuestionable. En todo caso, y habida cuenta que a partir del mencionado fallo, es la doctrina que debe aplicarse, lo previsible es que los conflictos que puedan seguir produciéndose se ciñan al control de las resoluciones administrativas que, en uso de las facultades contenidas en la LODR, procedan a la modificación de los términos de las distintas convocatorias.

No podemos concluir esta reflexión sino trasladando nuestra opinión de que, siendo legítimas las distintas concepciones existentes sobre el Alarde, lo auténticamente lamentable es la manifiesta y reiterada incapacidad de los colectivos involucrados y de las propias instancias públicas para lograr que una celebración festiva discurra por los cauces pacíficos exigibles y sin necesidad de las intervenciones gubernativas, policiales y judiciales hasta ahora siempre presentes.

Tal vez esta tónica haya empezado a romperse el presente año, primera ocasión en que las partes implicadas en el Alarde de San Marcial de Irún han decidido aceptar los términos de la Resolución de la Dirección de Seguridad Ciudadana del Gobierno Vasco y no acudir a la vía judicial. 